\title{
Interaction Ritual Chains and Sustainability of Lockdowns, Quarantines, "Social Distancing" and Isolation during the COVID-19 Pandemic
}

\author{
Saša Božić \\ University of Zadar, Department of Sociology, Croatia \\ e-mail:sbozic@unizd.hr
}

\begin{abstract}
National and local governments around the world introduced lockdowns, quarantines, "social distancing" and isolation to curb the global pandemic of COVID-19. While these measures were arguably successful in preventing the potential dire consequences of an uncontrolled pandemic, they also deeply influenced societies at the micro-, meso- and macrolevels. They disturbed interaction ritual chains, the building blocks of social reality as conceived in Randal Collins' interaction ritual theory. This article identifies and discusses the social effects of lockdowns, quarantines and isolation measures. It addresses interruptions of interaction ritual chains and consequent problems in building up emotional energy and their impact on overall solidarity; the sustainability of economic classes as circuits of monetary exchange; the consequences of closed interaction ritual markets; the disturbance of the interaction ritual structure, the loss of emotional energy, rising violence in isolated households; as well as the consequences of isolation in one-person households. The article also addresses micro and meso-level strategies for coping with lockdown and isolation, particularly the potential of computer-mediated interactions to substitute face-to-face interaction; ability of emotionally entrained mass audiences to sustain overall solidarity through creating new "sacred objects"; and the emergence of negative emotional energy within previously energised groups and a consequent defiance to introduced measures.
\end{abstract}

Key words: interaction ritual chains, interaction ritual theory, lockdown, quarantine, social distancing, isolation, COVID-19. 


\section{Introduction}

After SARS-CoV-2 started spreading, causing mass infections and overburdening health systems worldwide, many governments introduced measures and recommendations by March 2020 which included "social distancing" and even lockdowns and mass quarantines in order to stop or at least minimize the impact of the pandemic. While the introduced measures vary greatly (see Hale et al., 2020) some local, regional and national governments applied more stringent methods including closing all non-essential shops, banning meetings of more than two people and requiring citizens to stay in their homes except for very short trips for food or medicine. Locally strict quarantines and even nation-wide temporary curfews and total lockdowns were also introduced.

The effects of the introduced measures managed to curb the pandemic but were immediately felt in the economy and everyday lives of citizens. Public discussions on the social and societal consequences of mass quarantines and lockdowns were mostly concentrated on durable changes and future scenarios for everyday life which included the emergence of higher levels of social control through new smartphone applications, disruptions in intergenerational interaction, deepening crisis of democracy, new work arrangements, particularly online working and flexible working hours. Social scientists reacted fast and at the time of writing this article (April and beginning of May 2020) projects addressing the COVID19 crisis and its consequences were already underway ${ }^{2}$.

Lockdowns, quarantines and measures of "social distancing" have multiple consequences across micro-, meso- and macrolevels of social reality. The main question that has to be answered concerns the risks of breakdown in social structure due to massive and sudden changes in the expectations and orientations of all social actors as well as emerging powerful constraints which disrupt networks of social relations. The aim of this article is to identify and discuss the social consequences of the introduction of lockdowns, quarantines, "social distancing" and isolation and assess the sustainability of these measures, from the perspective of Interaction ritual theory (IRT) introduced by Randall Collins $(1975,2004 a)$. It will address the effects of the introduced meas-

$\mathbf{1}$ The term "social distancing" is widely used by infectologists and epidemiologists and refers to "the prac-
tice of maintaining a greater than usual physical distance from other people or of avoiding direct contact
with people or objects in public places during the outbreak of a contagious disease in order to minimize
exposure and reduce the transmission of infection" (Marriam-Webster Dictionary, 2003). The term was
widely used in public discourse and the media during the first months of the pandemic. The negative
connotation of the term "social distancing" which implies detachment of previously socially close actors
or severance of social ties as well as distancing based on social, ethnic and other attributes was addressed
by journalists and medical professionals (see World Health Organisation, 2020). The term physical dis-
tance was offered as a more accurate term and subsequently widely accepted in the media. 2 Already by 16 April 2020 there were more than 200 recorded projects, articles, analyses in progress (Matias and Leavitt, 2020). 
ures on the interruptions of interaction ritual chains (IRC) and the consequent problems of building up emotional energy (EE) as well as the impact of such interruptions on overall solidarity; the sustainability of economic classes as circuits of monetary exchange; the consequences of closing down many interaction ritual markets (i.e. cultural and sport events, churches and other places of worship etc.); the disturbance of interaction ritual (IR) structure through the imposition of greater than usual physical distance, mask wearing and pressure to shorten contact. It will address the loss of $\mathrm{EE}$ as well as rising violence in isolated households, in addition to the consequences of isolation and IRC interruption on the sustainability of individual personalities in one-person households. Finally, it will deal with strategies on the micro and mesolevel used in order to cope with lockdowns and isolation. It will particularly address the ability of computer-mediated interaction, now largely employed by everyone who practises physical distancing, isolation or is quarantined, to substitute face-to-face interaction and produce enough EE, sustain IRC and thereby preserve the "building blocks" of social reality and wider societal structures.

\section{Collins' Interaction ritual theory}

The microsociological theory of Randall Collins (1975, 2004a, 2008) is based on Durkheim's (1912/1965) work on social rituals ${ }^{3}$, collective effervescence and solidarity as well as Goffman's $(1967,1983)$ work on focused encounters and more broadly IRs which are embedded in wider structural and cultural units. Goffman inspired Collins to reconceptualise the social world as a world of constant flux and variation based on the ebbs and flows of daily, continuous small rituals. Variation in the intensity of rituals which leads to variation in social patterns is particularly important. This does not take place on the macro-level of society but on the level of local, stratified and conflictual memberships (Collins, 2004a).

From Collins' (1981) perspective IRs are the "microfoundation" of society through which social interaction, class cultures and more generally group life develop and change through time. IRCs of micro-encounters produce the central qualities of social organisation, i.e. authority, property, and group membership, through the creation of cultural symbols and EE (Collins, 1981:985). In Collins'view (1981:987-988) "state", "economy", "culture" or "social class" do not have an independent reality as independent macroentities nor do they act but are accruement of individual acting across different kinds of collections of microsituations. This implies that active agents in sociological explanations are actually microsituational and "social patterns, institutions, and organizations are only abstractions from the behavior of individuals and summaries of the distribution of different microbehaviors in time and space" (Collins,

3 Collins' theory differs from Durkheim's because of its strong focus on repetitive social interactions within encounters and its emphasis on patterns that emerge through repetition (von Scheve, 2016). 
1981:989). The only reason why there is a continuous social reality is because many individuals perform their microbehaviours repeatedly. Consequently, "structures" change only after the individuals who enact them change their microbehaviors ${ }^{4}$. Different macrostructures or events can be translated into these kinds of aggregations of micro-events 5 (Collins, 1981; 1981/2015).

The main building blocks of meso- and macrostructures are IRs which enable interaction here and now. These interactions harbour the agency of social life including intentionality, consciousness and emotions. The initiating conditions for the successful IR, but also the main ingredients of an IR, include at least several important conditions:

1. Two or more people are physically assembled in the same place, so that they affect each other by their bodily presence, whether it is in the foreground of their conscious attention or not.

2. There are boundaries to outsiders so that participants have a sense of who is taking part and who is excluded.

3. People focus their attention upon a common object or activity, and by communicating this focus to each other become mutually aware of each other's focus of attention.

4. They share a common mood or emotional experience" (Collins, 2004a:48).

These ingredients of IRs are mutually reinforcing, but the key elements, i.e. mutual focus and shared emotions, enable a process within which participants' mutual entrainment of emotion and attention produce a shared emotional and cognitive experience. The successful combination of ingredients of the IR produce higher levels of mutually focused and emotionally shared attention and the rituals result with: group solidarity and a feeling of membership; EE in the individual which includes confidence, elation, strength, enthusiasm and initiative; symbols that represent the group and feelings of morality, i.e. the sense of rightness in adhering to the group and defending it against transgressors (Collins, 2004a:49).

EE is the most important "product" of IRs but it is essential that participants physically participate and are co-present. Different mediated communication technologies can only have limited outcomes and cannot produce elevation and enthusiasm due to

${ }^{4}$ Collins $(1981,1981 / 2015)$ does not imply that a causal explanation must be microsituational in its entirety. There are references to reified macroentities that individuals make in microsituations but we can realistically determine only three pure macrovariables: the dispersion of individuals in physical space, the amount of time that social processes take (including temporal patterns of intermittent and repeated behaviours) and the numbers of individuals involved.

${ }^{5}$ However, a particular micro situation does not have to be necessarily linked to all other places and times where interactions take place and some local "ripples" do not have a very wide reach (Collins, 1988:245). 
the lack of micro-details of interaction (Collins, 2004a:54; 2018:248-249). Further on, individuals who participate in successfully performed rituals are motivated to feel initiative and enthusiasm in other rituals and re-enter repetitive IRs but also to pursue EE maximisation in IRs within different social occasions.

Nevertheless, high levels of emotional entrainment, in Durkheim's (1912/1965) terms "collective effervescence", are short-lived. The sustainability of solidarity based on the enthusiasm of individuals will depend on the successful transformation of short-term emotions into long-term emotions. If they are stored in symbols that reinvoke them, it is possible to activate emotional memories and meanings and thus affect group interactions, and personal identities in the longer run (Collins, 2004a:81). Collective effervescence and individual EE are particularly charged within focused crowds of active participants in large gatherings. Emerging symbols then circulate among the participants after the ritual is performed however only in a second-order, conversational ritual. Therefore they have to be recharged in the next assembly (Collins, 2004a:83). In contrast to large focused crowds, individualised encounters produce a momentary level of intersubjectivity which motivates participants to repeat it (Collins, 2004a:8384 ). Hence the symbols of personal identities and reputations are small tokens of social relationships (and of business relationships), with "lesser momentary intensity than audience symbols but used so frequently and in self-reinforcing networks so as to permeate their participants' sense of reality" (Collins, 2004a:87).

Individuals navigate through different encounters - from practical and emotionally poor to energising and solidarity-inducing ones. They will choose the ones that suit their cultural capital within different interaction markets: the marriage market; the dating market, different sexual markets, friendship market, as well as material markets, financial markets and consumer markets which are dependent on IR market's crucial social component. The markets for IRs represent the meso-level of social reality and provide a connection between micro and macrostructures. Individuals invest emotional, social and material resources in these markets depending on the possibility to attain EE payoff (Collins, 2004a:171).

On a macro-level Collins $(2000 ; 2004 a)$ suggests a micro-translation of the Weberian dimensions of class, status and power. He conceives the entire structure of economic classes as a variety of circuits of money used to enact particular kinds of social relations. He is specifically referring to social relations as interactional enactments of the economic class structure, including the world of occupations, commerce, credit and investment (Collins, 2000; 2004a:263). Classes ${ }^{6}$ are not ordered in a perfect hierarchical pyramid. They exist as overlapping transactional circuits of hugely different scope

${ }^{6}$ Collins (2000, 2004a:265-266) distinguishes seven classes: a financial elite, an investing class, an entrepreneurial class, celebrities, a variety of middle class / working class circuits, disreputable or illegal circuits and an ultimate lower class. 
and content. They also differ in the particularity and anonymity of connections as well as the type of control they exert. The most important difference between these circuits is their orientation towards either economic manipulation or consumption. They create different individual experiences of economic relations and ultimately different subjective worlds (Collins, 2004a:268).

Taking into consideration all the elements of IRT, one can infer that the decisions made within governmental organisations at a nation-state level to isolate individuals and families in their homes must have an enormous impact on the structure of IRs, on an individual as a cluster of "retrieved" and reflected IRs, on organisations, networks as well as on IR markets and classes as economic circuits of economic manipulation and consumption. I shall now concentrate on the consequences of quarantines, "social distancing" and isolation at a macro-level as the aggregation of micro encounters across time and space (Collins, 1992:90), on the structure of IRs, EE and solidarity, on an individual in isolation and on the coping strategies and sustainability of introduced measures.

\section{Social consequences of lockdowns, quarantines, "social distancing" and isolation from IRT's perspective}

Government decisions regarding lockdowns, isolation and physical distancing in everyday interactions have the following consequences, from the macro- and meso- to the microlevel:

a) A great number of IRCs that constitute organisations and networks but also give operational existence to larger institutions are disturbed or are exclusively computer-mediated.

Given that all meso- and macroformations depend on the repetitive performance of IRs in the daily lives of a great number of individuals, the decision to introduce lockdowns on communities, regions and even impose temporary curfews on whole nations $^{7}$, should have a tremendous effect on all levels of social reality. Collins' theory emphasises that institutions and organizations are only abstractions from the behaviour of individuals and extractions of the distribution of different microbehaviours in time and space (Collins, 1981:989). Additionally, the maintenance of institutions depends on the regular performance of rituals and sometimes on formal rituals that have to be performed in co-presence (Dacin, Munir and Tracey, 2010). Therefore we can extrapolate predictions about the massive disruption in social structure in case of the sudden interruption in IRCs and the suspension of microbehaviours that make up organisations, institutions and wider macrostructures.

${ }^{7}$ E.g. Albania, Cyprus, El Salvador, Serbia etc. 
By the beginning of May 2020 such disruptions in social structure and the disintegration of organisations and institutions or wider macrostructures had not occurred ${ }^{8}$. Networks, organisations and institutions owed their perseverance during the first several weeks of lockdown to interaction media and their ability to sustain a mediated co-presence and to enable the continuation of IRCs. Daily tasks, routines and microbehaviours that make networks, organisations and institutions were preserved through online communication.

Furthermore, it seems that interaction media can generate shared attention and emotion as well as produce some levels of solidarity among physically distant group members. Contrary to Collins' (2004a:54) view that various interaction media are not able to produce a sufficient amount of EE without bodily presence, lack the possibility to mediate the micro-details of the IR experience and are unable to express participation in the group and confirm identities in groups, DiMaggio, Bernier, Heckscher and Mimno (2019) produced the opposite evidence. They emphasise that, although online IRs do not operate in the same way as face-to-face situations, the main features of IRs can still be maintained without physical co-presence. In some cases online IRs can even be used to change identities (Maloney, 2013). Interaction media enable at least the bare minimum for the continuation of IRCs and thereby the sustenance of micro-, meso- and macrosocial structures.

Beyond the mediated interaction in networks and organisations, the interruption of IRCs on all levels of social reality discloses problems in building up emotional energy (EE) and impacts solidarity. Previous research on disasters (Thornburg, Knottnerus, Webb, 2007) describes them as a profound experience of the disruption of everyday ritual practices, loss of orientation and meaning. A pandemic is a specific type of disaster that does not start as abruptly as earthquakes, tornados or terrorist attacks. However, abruptly introduced lockdown measures in many countries pose a significant test to social resilience because high levels of EE and high levels of emotional entrainment, in Durkheim's terms "collective effervescence", are short-lived. The inability to repeat IRs and reaffirm belonging and solidarity under the circumstances of lockdown and isolation challenges social cohesion over prolonged periods of time. The main reason that the social structure seems mostly unharmed even after a month of general lockdowns rests in the fact that EE is produced through successfully performed rituals in the longer run. EE does not depend on dramatic emotions but on confidence result-

8 E.g. demonstrations and storming of the statehouse in Michigan, USA (British Broadcasting Corporation $[\mathrm{BBC}], 2020$ ), demonstrations and arrests in Berlin, Germany (Euronews, 2020). The lack of fervour and later violence can be explained by the fact that the EE of these crowds never reached the point at which the emotional power of the group could become embodied in a violent minority. Collins (2008:449) claims that "violence mainly comes from the emotional flow of an assembly whose attention has become sharply focused, whether as companions, audience, or antagonists". The lack of general support for such demonstrations as well as of a clear focus of demonstrators probably resulted in a much lower build-up of tension. 
ing from perpetually performed IRCs. Positive and transient emotions such as joy, enthusiasm and sexual passion help build up the store of EE (Collins, 2004a:130). Also, the circulation of positively charged symbols that emerged in previous IRs enables the storage of EE which allows the vast number of individuals to remain focused, engaged and optimistic in the face of challenges brought by lockdowns and quarantines, for at least a limited amount of time. Beside interaction media, online IRs and residues of EE from previous IRCs, there are other social factors which can explain why the social structure can be at least temporarily preserved under lockdown and isolation. They will be discussed later in a segment dedicated to coping strategies.

b) Economic classes as circuits of monetary exchange, particularly those who are focussed on consumption, are disturbed or broken ${ }^{9}$.

Economic classes are conceived in IRT through material wealth as consumption experiences and wealth as control over occupational experiences (Collins, 2004a:263). From this perspective the entire structure of the economic class is dependent on various circuits of money used to enact particular kinds of social relations within the world of occupations, commerce, credit, and investment (Collins, 2000:21). There are seven circuits of monetary exchange and they include the financial elite, investing class, entrepreneurial class, celebrities, a variety of middle-class / working-class circuits shaped by occupational markets and the networks of information and contact that sustain them, disreputable or illegal circuits and an ultimate lower class on the margins of society (Collins, 2004a:265-268). The hierarchy of wealth and income reveals that the proportion of money that translates into actual material consumption increases among middle and lower income classes, while for the lowest income levels, money is almost exclusively reserved for consumption goods (Collins, 2004a:264). Middle and working classes may spend "small amounts on repetitive consumer expenditures in impersonal retail organizations” (Collins, 2004a:267) and occasionally have large single expenditures for a house or a car. However, the experience connected to these consumer expenditures has a profound influence on the long-term meaningful ties and life trajectories of members of those classes ${ }^{10}$. For almost all classes, the experience of financial circuits and transactions is based on personal contacts, and lockdowns have an impact on the IRCs of all classes; however, the financial elite and less personally involved investing class members have more resources and accumulated EE from

${ }^{9}$ Only the financial elite and investing class are still able to perform monetary manipulation and sustain their circuits. Even celebrities are unable to perform their daily rituals and produce mass focus that would benefit them and the organisations they work for. Celebrities who are particularly affected are late show hosts, sport stars, musicians and film stars.

10 Although all entrepreneurial circuits suffered a blow by the lockdown and isolation measures because successful entrepreneurial rituals depend largely on face-to-face interaction and production of enthusiasm (Goss, 2008) they were also much more capable of circumventing the imposed measures and continuing the coordination of their circuits of exchange. 
previous successful transaction rituals to be able to create new frameworks and spaces for the continuation of their interaction and transaction routines.

Lockdowns, quarantines and isolation do not only endanger the income and material sustainability of lower economic classes but also curb down IRs that revolve around money making, spending and consuming. Furthermore, many members of the middle and working classes do not occupy positions within the working place which would allow for greater amounts of EE to emerge, which makes consumption the most important place for accumulating EE. Importantly, the experience of online shopping and highly structured and disciplined grocery shopping during pandemic lockdowns ${ }^{11}$ cannot replace the experience of shopping and consuming within IRCs which are enacted individually, but also with family members or in dyads and groups of friends who share particularised cultural capital ${ }^{12}$. Even small and irregular IRs among anonymous shoppers and salespersons in city markets can produce excitement and give meaning to social encounters (Blackledge and Creese, 2018).

Elements of consumer rituals are integral to eliciting pride, a positively valenced and enduring emotion, responsible for reinforcing group hierarchies and emotional bonds (Sredl, 2010). Consumer pride depends on the display and use of goods and services and emerges when others confirm the self as a valuable participant in social interactions (Sredl, 2010). The loss of ability to display acquired goods and services as well as generally consume with others during lockdown impacts all individuals in the middle and working classes and consequentially all social relations built around money making, shopping and consuming. In this sense, IRCs in many cases stopped for at least a month, bringing middle and working class circuits to a standstill. The idea that these circuits will easily recover and pick up once lockdown and isolation measures are over does not correspond with the economic and social reality of the middle and working classes. The loss of material support for carrying out future IRs in combination with shame, another lasting but devastating emotion (Scheff, 2003) that arises from the inability to support families and display social worth through consumption, will curtail meeting, spending, bonding and the fast revival of economic circuits based on consumption.

c) Interaction markets which provide high levels of EE are closed alongside with material markets which enable all interaction markets and EE-payoffs.

11 Chaotic panic buying mostly emerged before or in the early stages of lockdown. After reserves were piled and epidemiological measures were introduced, shopping became a much more structured and disciplined exercise.

12 Particularised cultural capital refers to words, specific knowledge, speech patterns, objects, memories and experiences that only members of the group share (Collins, 1975; 2004a). 
The main good in social interaction is EE, generated through experiences of group solidarity (Collins (2004a:145). Individuals are motivated to increase their EE which means that they will prefer participation in IRs which result in more solidarity and which have lower costs of participating. This claim entails the idea that there is a market for ritual participation that shapes the distribution of individual behaviour (Collins, 2004a:145). While some IR markets are completely closed during lockdown (cultural events, churches, sports' events etc.), some became increasingly dependent on online communication (marriage, sexual encounters, friendship markets etc.). Closing markets that enable gatherings of larger crowds took away the possibilities for the accumulation of significant amounts of $\mathrm{EE}$ and confined members of many groups to online communication in dyads or emotionally flat online meetings of smaller groups.

Recent research has confirmed that there is a clear relationship between social-morphological densities and emotional excitement. High levels of collective effervescence are an important outcome of interaction dynamics developing within crowds (Liebst, 2019). Big meetings and crowds produce excessive EE that overflows individual bodies and creates collective and individual enthusiasm. However, this enthusiasm cannot hold for longer periods of time. Research on megachurches reveals that many megachurch goers describe a hunger or thirst for new sermons and a feeling of loss when sermons are skipped (Wellman, Corcoran, Stockly-Meyerdirk, 2014).

This has an impact on solidarity within various groups. Generalised mass-audience symbols which emerge after EE is produced in gatherings depend on the reassembling of these groups (Collins, 2004a:87). Generalised symbols cannot be recharged through ordinary IRs in everyday life (Collins, 2004a:87) and lockdown measures are literally disintegrating networks and groups which emerge from and sustain themselves through large gatherings. Event managers who develop material markets and designs that support the production of EE are also aware that events and festivals they design and manage are not sustainable without increasing the output of EE in the longer run (Richards, 2014).

Further on, large gatherings such as those in sports, enable additional smaller IRs before, during and after the main events in bars, parking lots etc., while sport fans sustain their group through additional rituals beyond game-specific situations which even include funerals and weddings (Cottingham, 2012). The study on megachurches reached similar findings. Small groups within a megachurch are enduring and very successful in creating support networks which secure group loyalty, while maintaining the EE generated in church services (Wellman et al., 2014:664). Large gatherings and smaller IRs revolving around these gatherings mutually reinforce each other and disruption in one or both hamper the production of EE, solidarity and the sustainability of groups emerging from different IR markets. Lockdowns froze many interaction markets, reduced individual choices, prevented individual EE building but also 
hindered group solidarity dependent on mass cultural, political, religious and sport assembling and reassembling.

d) IR structure is disturbed and physical co-presence, a common focus of attention, common emotional mood, rhythmic coordination and synchronisation (Collins, 1975) are particularly affected due to physical distancing, wearing of face masks and pressure to shorten any contact which means that $\mathrm{EE}$ is much harder to produce.

IR reveals socially important micro-processes in which participants develop a mutual focus of attention and become entrained in each other's bodily micro-rhythms and emotions (Collins, 2004a:47). Introduced measures against the pandemic included physical distancing in public indoor and outdoor spaces and, in many countries, mandatory wearing of surgical masks or if those masks were unattainable, substitutes that cover almost all parts of the face which are involved in signalling emotions through facial expressions. The success of an IR depends on subsequent EE exchange which increases only if physical co-presence, mutual focus of attention and common emotional mood are achieved (Boynes and Luery, 2015:151). IRs under masks and with a greater than usual physical distance (see Sorokowska et al., 2017), strongly influence building up EE through co-ordination of communicational micro-rhythms in everyday situations. Mutual focus of attention is an essential component for a ritual to work properly. It has to develop spontaneously without reflection or a specific concern that it is happening (Collins, 2004a:50). Masks and greater physical distance hinder such spontaneity and emotional entrainment which might cause IR to fail.

Considering that all EE and solidarity building across all social situations is dependent on successful IR performance it can be inferred that the long-term costs of imposed restrictions to the IR structure, i.e. physical distance, face mask wearing and a pressure to shorten interactions, will be observable in lowered enthusiasm to repeat IRs, declining solidarity within various groups, weakening feelings of morality or the sense of adhering to the group (Collins, 2004a:49). On the other hand, many groups with already accumulated high EE, with strong symbolism and feelings of group solidarity, strong group boundaries and a strong sense of moral rightness may defy "social distancing" and epidemiological measures and openly express their defiance in public, performing IRs in the face of new rules and authorities who are often perceived and portrayed as "transgressors".

e) A great number of individuals are confined to a small number of IRs, mostly within nuclear families for a prolonged time and their EE supply depends on the quality of previous IRCs within a family. 
Lockdown and isolation measures have made nuclear families the main, and in many cases the only unit within which unhindered IRs are possible. Families with a more egalitarian structure which already had plenty of natural IRs and have previously accumulated an abundant amount of EE for their members most probably preserved their internal solidarity and the sense of adhering to the family. Nevertheless, prolonged confinement and reduced possibility to re-enter other IRCs in combination with the general tendency to lose EE in repetitive and socially dense rituals ${ }^{13}$ over time, can pose a significant problem to even the most "functional" families during lockdown.

Importantly, most nuclear families are not egalitarian and display features of stratified IRs and particularly of power and status rituals. IRT predicts that individuals acquire or lose $\mathrm{EE}$ in both power and status interactions whereby order-givers maintain and sometimes gain EE while order-takers lose it (Collins, 2004:a118). Those who are being dominated in a power situation, or excluded from a status situation will experience low levels of $\mathrm{EE}$ in the form of depression and shame (Collins, 2004a:121). Isolation accentuates this dynamic even more. Without a possibility to gain EE outside strongly stratified IRs many dominated individuals face additional EE loss and are vulnerable to abuse.

Even worse, isolation may increase the potential for violence. Already by the beginning of April 2020 the UN warned that global lockdowns resulted in a "horrifying surge" in domestic violence (Neuman, 2020). Michalski (2005:632) argues that intimate partner violence or "situational couple violence" tends to flourish in social space where partners have a high degree of intimacy, relational involvement, and a shared proximity; a relative absence of mobility opportunities; a high level of functional interdependence; greater social isolation, or the relative absence of partisans to intervene; weak external, independent networks with few cross-cutting ties etc. The physical isolation of such socially isolated couples and families gives an additional situational momentum for the escalation of violence. Collins (2008:148) emphasises an escalation chain as well as the continuous entrainment of victim with aggressor as a central micro-process within different types of domestic abuse and violence situations. The social and physical isolation increases the mutual focus of violently entrained partners and creates circumstances that favour the escalation of abuse and violence.

f) Considering the vast number of one-person households in Western countries ${ }^{14}$, a considerable number of individuals lost the opportunity for any non-mediated

13 Social density refers to the proportion of time spent with the people in physical presence. It is an aggregate of chain situations over time. (Collins, 2004a:116).

${ }^{14}$ The total number of private households within the EU-28 rose from 206 million in 2009 (the earliest period for which this indicator is available) to 220 million by 2016 . More than $50 \%$ of households in Sweden, Denmark and Lithuania were composed of people living alone in 2016. Capital regions of Berlin, Paris and Oslo had more than 50\% of single-households in 2016. (Eurostat, 2017) 
IRs which makes only individuals with high residues of EE and those capable of retrieving symbols and invoking past IRs adept in enduring isolation ${ }^{15}$.

The result of successful rituals is an individual who apportioned collective energies and representations. Social encounters result in a residue of emotions and symbols carried by human bodies. Solitary moments reveal an interplay of emotions and symbols through reflecting backward in time, forward to future encounters or into an inner space of thought and mind (Collins, 2004a:345).

The shape of IRCs can be recognised in internal conversations which are not unbounded or random (Collins, 2004a:184). The thought chains of inner conversations reveal a process in which one symbolic representation leads to another because these representations have been charged with membership significance and because they are weighted emotionally by recent interactional usage (Collins, 2004a:202-203). However, the inner depths of thought can be scattered, unfocused, episodic and inarticulate because inner IRs do not have to be necessarily successful, particularly if individuals are unable to produce methods for entraining themselves (Collins, 2004a:219). Only true non-gregarious introverts who can obtain strong EE from some third-order circulation of symbols (Collins, 2004a) are able to lead mostly solitary lives. Many occupants of single households who are not introverts rely strongly on close and personally experienced IRCs as well as on second-order symbols used in conversation. "Thinking always takes place in some situation in time, and thus is surrounded by overt IR chains, which both set the starting point for internal thinking, and supply its symbolic and emotional ingredients (Collins, 2004a:184)". Isolation takes away surrounding overt IRCs and inadvertently causes problems in organising thoughts and mobilising emotions for those who do not rely on internalised symbols in their "inner lives". Consequently, such single household occupants will experience loss of $\mathrm{EE}$ and possibly depression during lockdown, or spend a great amount of time on various interaction media because their third-order use of symbols through thinking is very dependent on their physical participation in IRCs, emotional entrainment from physical encounters and second-order use of symbols in conversation.

\section{Coping strategies and sustainability of lockdown and isolation}

Social structure at a time of crisis is sustained by creating a mass focus of anonymous crowds via mass media that can generate impersonal symbols through mass emotional entrainment. During the COVID-19 crisis a strong mediated focus on doctors and

15 Already by the end of March 2020 the European Public Health Alliance identified anxiety, apathy, depression and panic as the main psychological consequences of social and physical isolation in different populations (particularly prisoners and children) after lockdown and "social distancing" measures were introduced (Zaharieva, 2020). 
nurses fighting the disease was created. They were mainly portrayed similar to soldiers fighting in "the front lines in a war", this time with SARS-CoV-2. They became a generalised symbol of emotionally entrained mass audiences (Collins, 2004a:87) or a sacred object (Durkheim, 1912/1965). Similar to the fire fighters after 9/11 terrorist attacks who already had ritual solidarity and group identity and who have suffered losses to their ranks (Collins, 2004a:93), doctors and nurses started to symbolise a joint effort, courage and resilience in the face of danger. Specific rituals of solidarity display have emerged and included spontaneous and sometimes organised clapping and singing on the balconies of many cities around the world.

Moreover, daily briefings by specially appointed medical experts in many countries managed to produce an additional focus and emotional entrainment of mass audiences and propelled these experts and some politicians ${ }^{16}$ to new stardom. They became additional symbols of the joint collective fight against the disease. Low-cost inputs through daily rituals, e.g. washing hands and staying at home, were presented as an important localised ritual that can be easily performed perpetually by everybody. For at least a limited amount of time, the performance of simple and inexpensive daily rituals enabled many people to stay focused, feel connected and dedicated to a common cause.

Nevertheless, based on earlier experiences (Collins, 2004b), the display of solidarity as well as energising and binding power of newly established symbols will dissipate. Mass display of solidarity in a repetitive ritual of clapping and singing for doctors and nurses of the quarantined populations around European and American cities lasted for several weeks. General rally behind the leaders (Erlanger, 2020), which followed the previous patterns of high support in the polls at the beginning of crisis, usually returns to "normal levels of support" (Collins, 2004b:54).

Interaction media also enabled the preservation of social structure, particularly by upholding daily, repetitive mediated IRs. Ling (2008:170) noticed that mediated interaction can be based on the symbols that were developed and sustained in co-present IRs but also develop in exclusively mediated interactions. These interactions include mainly dyads or small groups of those who are already engaged in IRCs offline and sustain their interaction through both offline and online communication. Even larger offline and online mixed groups can support their IRCs through a combination of offline and online rituals which can reinforce each other and create hybrid communities (Simons, 2019). However, not many online groups which sustain their IRCs and

\footnotetext{
16 E.g. Dr Anthony Fauci, member of the White House Corona Task Force in the US whose name is on mugs for sale, Dr Vili Beroš, Minister of Health of the Republic of Croatia who received drawings and congratulations from children. General support for politicians in power at the beginning of the Corona pandemic also rose significantly and followed the patterns of rituals of solidarity at the beginning of a wider crisis (Collins, 2004b).
} 
build their solidarity exclusively online were identified and researched so far ${ }^{17}$. The Internet almost always plays an important supplementary role, yet it is not a site of IRs but rather a facilitator of the speed and scope of face-to-face mobilisation (Di Maggio et al., 2019). Therefore, it is reasonable to assume that a prolonged maintenance of all IRCs, from friendships to large organisations and institutions, exclusively via interaction media and online communication, can reach a breaking point after which the IRC is inoperative or recreated face-to-face in an act of defiance to lockdown.

Defiance, disregard for the introduced measures, feelings of righteous anger against transgressing individuals, groups and institutions could become widely spread among previously mobilised groups and some form of protest but also violence could become a coping strategy for individuals and groups if lockdown measures become too strict and last for a prolonged period of time. While Collins (2004a) mainly deals with positive $\mathrm{EE}$ in the form of enthusiasm and elation that leads to higher solidarity, Boynes and Luery (2015) emphasize negative EE in the form of anger, hatred and resentment which rallies group members against a threat imposed by others. According to Boynes and Luery (2015:161) "the greater the degree of positive emotional energy derived from an individual's solidarity with a group the greater the individual's negative emotional energy will be against the opposing group". They also state that "the negative EE will be a direct function of the ritual density of the group and the level of conflict (or perceived threat) between the groups" (Boynes and Luery, 2015:161). Such groups and networks can experience lockdown measures as serious transgressions against group values and boundaries. They are among candidate groups to openly defy and oppose lockdown and isolation measures as well as institutions that introduce and enforce them.

Only several instances of disobedience and collective demonstrations by previously energised, mostly right wing groups, who share solidarity supported by symbols of individual liberty in the face of "elites" and state institutions and who have built strong boundaries towards all non-members were recorded by the beginning of May $2020^{18}$. Nevertheless, one can expect many other groups which developed a strong sense of solidarity and provided their members with a high level of EE prior to lockdown measures to gradually develop resentment towards these measures and institutions which introduced and oversaw them, if the emotional and solidarity costs of these measures are high.

17 An example of an exclusively online, goal oriented community with a strong sense of belonging and a capacity to influence identities is described by Maloney (2013).

18 E.g. demonstrations and storming of the statehouse in Michigan, USA (British Broadcasting Corporation $[\mathrm{BBC}], 2020)$, demonstrations and arrests in Berlin, Germany (Euronews, 2020). The lack of fervour and later violence can be explained by the fact that the EE of these crowds never reached the point at which the emotional power of the group could become embodied in a violent minority (Collins, 2008). 
Finally, non-introverted individuals who live alone and endure isolation might rely additionally on the rituals of self-solidarity and develop their devices for getting themselves focused i.e. their methods for entraining themselves (Collins 2004a:219) ${ }^{19}$. Inner IRs constitute chains of thought that are interwoven with external IRs and can also supply an individual with an EE. The space of inner thought can create solidarity with oneself while used symbols become recombined and tested for future projects and symbolic alliances (Collins, 2004a:219). However, only those with elaborate, long-lasting and firmly entrained inner IRs who are a part of wider, cohesive, mostly intellectual longdistance networks and even epistemic communities, e.g. scientists, experts and professionals with real-life impact (Cross, 2013), can rely on EE emerging from inner IRs for a prolonged period of time without the invariable recharging through second and first-order rituals. All others have to re-energise regularly in face-to-face IRCs or at least second-order rituals or face a loss of energy, depression and even incoherent and inarticulate thought.

\section{Conclusion}

National and local governments around the world have introduced lockdowns, quarantines, "social distancing" and isolation to curb down the global pandemic of COVID-19. While these measures were successful in preventing the dire consequences of an uncontrolled pandemic, they have also deeply influenced societies on micro-, meso- and macrolevels. Most of all, they disturbed IRCs, the building blocks of social reality as conceived in IRT. A great number of IRCs that constitute organisations and networks but also give operational existence to larger institutions, have been disturbed or exclusively computer-mediated. Economic classes as circuits of monetary exchange, particularly those reduced to consumption, have been disturbed or broken. Interaction markets which provide high levels of EE have been closed alongside the material markets that support them. Also, the very structure of IRs has been disturbed and physical co-presence, a common focus of attention, common emotional mood, rhythmic coordination and synchronisation have been particularly affected due to physical distance, face mask wearing and pressure to shorten any contact which means that $\mathrm{EE}$ is much harder to produce in most public interactions. A great number of individuals have been confined to a small number of IRs, mostly within their nuclear families for a prolonged time and their EE supply has depended almost exclusively

\footnotetext{
19 Rituals of self-solidarity include even cursing which builds up energy over the course of uttering the formula, getting selfentrained in its rhythm (Collins, 2004a:208). Any solitary action which produces entrainment and connects the person with previously experienced interactions including thoughts, movements, selfproduced sounds can result in selfentrainment and heightened EE. Singing and even smoking can invoke previous social experience in a temporarily isolated body (Collins, 2004a:304).
} 
on a small number of IRs. Finally, taking into consideration the vast number of oneperson households in Western countries, a considerable number of individuals have lost opportunities for any non-mediated IRs.

Coping strategies in the form of recreating IRCs through interaction media have only a limited effect on the sustainability of introduced measures. Most individuals, dyads, networks and groups combine online IRs and face-to-face IRs. Only exceptional cases of IRCs performed exclusively through interaction media, were identified before the pandemic. The loss of EE and dwindling solidarity are predictable outcomes for many networks and groups in case of a prolonged lockdown. Groups that were already supplying a significant amount of EE to their members through strongly charged IRCs and who relied on strong solidarity and circulation of symbols can, on the other hand, experience lockdown measures as serious transgressions against the group's values and boundaries. They are among candidate groups to openly defy and oppose lockdown and isolation measures as well as institutions that introduce and enforce them. Additionally, the emotional entrainment of mass audiences through televised daily rituals and display of solidarity with doctors and nurses who became a "sacred object" started to dissipate already after several weeks.

Rituals of self-solidarity as a successful internal coping strategy through inner IRs and third-order use of symbols are only helpful to limited populations and cannot be performed for a longer period of time by most individuals without recharging through second and first-order rituals, i.e. conversations and face-to-face IRs. Granted the premises of IRT that the social structure of all societies and macroformations is built and sustained through microinteractions in EE-producing IRCs, lockdowns, quarantines, "social distancing" and isolation are socially sustainable for a very limited amount of time.

Finally, Randall Collins' interaction ritual theory (IRT) has proved to have a high explanatory and predictive power. IRT is not formulated as an axiomatic scheme, however its formal propositions and discursive schemes (Turner, 2013) allow us to analyse and assess the social effects of lockdowns, quarantines and isolation measures by identifying the main disruptions in the building blocks of social reality - interaction ritual chains. The main proposition of IRT on the fundamental importance of building and sustaining emotional energy and its impact on overall solidarity and its sustainability proved again to be valid. Considering that all EE and solidarity building across all social situations is dependent on successful IR performance it was inferred that the long-term costs of imposed restrictions to IR structure, i.e. physical distance, face mask wearing and a pressure to shorten interactions, will be observable in lowered enthusiasm to repeat IRs, declining solidarity within various groups, weakening feelings of morality or the sense of adhering to a group (Collins, 2004a:49). Alternatively, many groups with already accumulated high EE, with strong symbolism and feelings 
of group solidarity, strong group boundaries and a strong sense of moral rightness ${ }^{20}$ will defy "social distancing" and epidemiological measures and openly express their defiance in public, performing IRs in the face of new rules and authorities who are often perceived and portrayed as "transgressors". From the time of writing this article in April and beginning of May 2020 to the time of its revision after peer reviewing in late October 2020 the number of demonstrations organised by socially, ideologically and politically diverse groups to express this defiance skyrocketed, and some groups even tried to physically assault and kill politicians who embody the transgression itself ${ }^{21}$. The development of such events across different continents could also prove Collins' (2004b; 2012:13) proposition that solidarity over time has the shape of a fireworks rocket: very rapid ascent, a lengthy plateau, and slow dissipation, i.e. a three-month plateau and six-month dissipation. The present insights on the performance of Collins' theory in explaining solidarity dynamics under conditions of severe interaction restrictions make it a strong candidate for more stringent testing.

\section{References}

1. Blackledge, A. and Creese, A. (2018). Interaction Ritual and the Body in a City Meat Market. Social Semiotics, 1-24.

2. Boyns, D. and Luery, S. (2015). Negative Emotional Energy: A Theory of the "Dark-Side" of Interaction Ritual Chains. Social Sciences, 4 (1): 148-170.

3. British Broadcasting Corporation (2020). Coronavirus: Armed protesters enter Michigan statehouse. https:/www.bbc.com/news/world-us-canada-52496514. (Accessed 2 May 2020)

4. Collins, R. (1975). Conflict Sociology: Toward and Explanatory Science. New York: Academic Press.

5. Collins, R. (1981). On the Microfundations of Macrosociology. American Journal of Sociology, 86 (5): 984-1014.

6. Collins, R. (1988). The Microcontribution to Macrosociology. Sociological Theory, 6 (2): 242-253.

7. Collins, R. (1992). The Romanticism of Agency/Structure versus the Analysis of Micro/Macro. Current Sociology, 40 (1): 77-97.

8. Collins, R. (2000). Situational Stratification: A Micro-Macro Theory of Inequality. Sociological Theory, 18 (1): 17-43.

9. Collins, R. (2004a). Interaction Ritual Chains. New Jersey: Princeton University Press.

\footnotetext{
20 Including political groups outside of the political party landscape, who mobilised parts of different social movements but mostly those who already questioned the authority of science and governmental institutions, e.g. the anti-vaccine movement and adherents of many conspiracy theories currently circulating within various overlapping social networks.

21 The most prominent case being the plan to kidnap, put to "trial" and execute the governer of Michigan by the "Wolverine Watchmen" extremist group.
} 
10. Collins, R. (2004b). Rituals of Solidarity and Security in the Wake of Terrorist Attack. Sociological Theory, 22 (1): 53-87.

11. Collins, R. (2008). Violence: A Microsociological Theory. New Jersey: Princeton University Press.

12. Collins, R. (2012). C-Escalation and D-Escalation: A Theory of theTime-Dynamics of Conflict. American Sociological Review, 77 (1): 1-20.

13. Collins, R. (2015). Micro-Translations as a Theory Building Strategy, in: KnorrCetina, K. and Cicourel, A. (Eds.). Advances in Social Theory and Methodology: Toward an Integration of Micro- and Macro-sociologies. Abingdon and New York: Routledge. (First published in 1981)

14. Collins, R. (2018). Sociologizing with Randall Collins: An Interview about Emotions, Violence, Attention Space and Sociology. European Journal of Social Theory, 21 (2): 245-259.

15. Cottingham, M. D. (2012). Interaction Ritual Theory and Sport Fans: Emotion, Symbols, and Solidarity. Sociology of Sport Journal, 29 (2): 168-185.

16. Cross, M. K. D. (2013). Rethinking Epistemic Communities Twenty Years Later. Review of International Studies, 39 (1): 137-160.

17. Dacin, M. T.; Munir, K.; Tracey, P. (2010). Formal Dining at Cambridge Colleges: Linking Ritual Performance and Institutional Maintenance. Academy of Management Journal, 53 (6): 1393-1418.

18. DiMaggio, P.; Bernier, C.; Heckscher, C.; Mimno, D. (2019). Interaction Ritual Threads: Does IRC Theory Apply Online, in: Weininger, E. B.; Larou, A. and Lizardo, O. (Eds.). Ritual, Emotion, Violence: Studies on the Micro-Sociology of Randall Collins. New York: Routledge.

19. Durkheim, E. (1965). The Elementary Forms of the Religious Life. New York: Free Press (Original work published in 1912).

20. Erlanger, S. (2020). Coronavirus Has Lifted Leaders Everywhere. Don't Expect That to Last. The New York Times. https:/www.nytimes.com/2020/04/15/ world/europe/coronavirus-presidents.html. (Accessed 16 April 2020)

21. Euronews (2020). German police arrest over 100 during anti-lockdown protest. https://www.euronews.com/2020/04/25/german-police-arrest-over-100-during-anti-lockdown-protest. (Accessed 2 May 2020)

22. Eurostat (2017). People in the EU - statistics on household and family structures. Eurostat. https://ec.europa.eu/eurostat/statistics-explained/pdfscache/41897. pdf. (Retrieved 30 April 2020)

23. Goffman, E. (1967). Interaction Ritual: Essays on Face-to-Face Behaviour. Garden City, N.Y.: Anchor Books.

24. Goffman, E. (1983). The Interaction Order. American Sociological Review, 48 (1): $1-17$.

25. Goss, D. (2008). Enterprise Ritual: A Theory of Entrepreneurial Emotion and Exchange. British Journal of Management, 19 (2): 120-137. 
26. Hale, T.; Petherick, A.; Phillips, T. and Webster, S. (2020). Variation in government repsonsed to COVID-19. BSG-WP-2020/031 Version 4.0. BSG Working Paper Series. University of Oxford. https://www.bsg.ox.ac.uk/sites/default/ files/2020-04/BSG-WP-2020-031-v4.0 0.pdf. (Retrieved 10 April 2020)

27. Liebst, L. S. (2019). Exploring the Sources of Collective Effervescence: A Multilevel Study. Sociological Science, 6: 27-42.

28. Ling, R. S. (2008). The Mediation of Ritual Interaction via the Mobile Telephone, in: Katz, J. E. (Ed.). Handbook of Mobile Communication Studies. Cambridge, Massachusetts: The MIT Press.

29. Maloney, P. (2013). Online Networks and Emotional Energy: How Pro-anorexic Websites Use Interaction Ritual Chains to (Re)Form Identity. Information, Communication and Society, 16 (1): 105-124.

30. Marriam-Webster Dictionary (2003). Definition of Social Distancing. https:// www.merriam-webster.com/dictionary/social\%20distancing. (Accessed 16 April 2020)

31. Matias, J. N. and Leavitt, A. (2020). COVID-19 Social Science Research Tracker. https://github.com/natematias/covid-19-social-science-research. (Retrieved 16 April 2020)

32. Michalski, J. H. (2005). Explaining Intimate Partner Violence: The Sociological Limitations of Victimization Studies. Sociological Forum, 20 (4): 613-640.

33. Neuman, S. (2020). Global Lockdowns Resulting In 'Horrifying Surge' In Domestic Violence, U.N. Warns. National Public Radio. https://www.npr.org/sections/coronavirus-live-updates/2020/04/06/827908402/global-lockdowns-resulting-in-horrifying-surge-in-domestic-violence-u-n-warns? $\mathrm{t}=1589289982602$. (Accessed 16 April 2020)

34. Reddy, S. G. (2020). Corona Virus and the Limits of Economics. Foreign Policy, March 2020. https://foreignpolicy.com/2020/03/31/coronavirus-pandemicrethinking-economics/. (Accessed 16 April 2020)

35. Richards, G. (2014). Imagineering Events as Interaction Ritual Chains, in: Richards, G.; Marques, L. and Mein, K. (Eds.). Event Design: Social perspectives and practices. London: Routledge.

36. Scheff, T. (2003). Shame in Self and Society. Symbolic Interaction, 26 (2): 239262.

37. Simons, I. (2019). Events and Online Interaction: The Construction of Hybrid Event Communities. Leisure Studies, 38 (2): 145-159.

38. Sorokowska, A. et al (2017). Preferred Interpersonal Distances: A Global Comparison. Journal of Cross-Cultural Psychology, 48 (4): 577-592.

39. Sredl, K. (2010). Consumer Pride: Emotion As a Social Phenomenon, in: Campbell, M. C.; Inman, J. and Pieters, R. (Eds.). Advances in Consumer Research Volume 37. Duluth, MN: Association for Consumer Research.

40. Thornburg, P. A.; Knottnerus, D. J. and Webb, G. R. (2007). Disaster and Deritualization: A Re-interpretation of Findings from Early Disaster Research. The Social Science Journal, 44 (1): 161-166. 
41. Turner, J. H. (2013). Contemporary Sociological Theory. Los Angeles: Sage.

42. von Scheve, C. (2016). Collective emotions in rituals: Elicitation, Transmission, and a "Matthew-Effect", in: Michaels, A. and Wulf, C. (Eds.). Emotions in Rituals: South Asian and European Perspective on Rituals and Performativity. London: Routledge.

43. Wellman, J. K.; Corcoran, K. E. and Stockly-Meyerdirk, K. (2014). "God Is Like a Drug...”: Explaining Interaction Ritual Chains in American Megachurches. Sociological Forum, 29 (3): 650-672.

44. World Health Organization (2020). COVID-19, Transcript of a WHO press conference. https://www.who.int/docs/default-source/coronaviruse/transcripts/who-audio-emergencies-coronavirus-press-conference-full-20mar2020. pdf?sfvrsn=1eafbff 0. (Retrieved 16 April 2020)

45. Zaharieva, R. (2020). The dangers of social isolation during a pandemic. European Public Health Alliance, March 2020. https://epha.org/the-dangers-of-socialisolation-during-a-pandemicl. (Accessed 16 April 2020) 


\title{
Lanci interakcijskih rituala i održivost zatvaranja, karantena, "socijalnog distanciranja" i izolacije za vrijeme pandemije COVID-19
}

\author{
Saša Božić \\ Sveučilište u Zadru, Odjel za sociologiju, Hrvatska \\ e-mail: sbozic@unizd.hr
}

\section{Sažetak}

Nacionalne i lokalne vlade diljem svijeta uvele su karantene, "socijalno distanciranje" i izolaciju kako bi usporile globalnu pandemiju COVID-19. Te su mjere bile uspješne u sprečavanju eventualnih teških posljedica nekontrolirane pandemije, ali su duboko utjecale na društva, na mikro-, mezo- i makrorazini. Najviše su poremetile lance interakcijskih rituala, građevne blokove društvene stvarnosti kako ih koncipira teorija interakcijskih rituala Randalla Collinsa. Ovaj članak identificira i raspravlja društvene posljedice karantena i mjera izolacije. Bavi se prekidima lanaca interakcijskih rituala i posljedičnim problemima u stvaranju emocionalne energije kao i njihovim utjecajem na ukupnu solidarnost; održivošću ekonomskih klasa kao mreža monetarne razmjene; posljedicama zatvaranja tržišta interakcijskih rituala; poremećajem strukture interakcijskih rituala; gubitkom emocionalne energije i rastom nasilja u izoliranim kućanstvima; sposobnošću emocionalno usklađenih masovnih publika da održe ukupnu solidarnost stvaranjem novih „svetih objekata“; pojavom negativne emocionalne energije u prethodno energetiziranim grupama te, posljedično, otporom uvedenim mjerama.

Ključne riječi: lanci interakcijskih rituala, teorija interakcijskih rituala, zatvaranje, karantena, socijalno distanciranje, izolacija, COVID-19. 